\title{
KETERBUKAAN INFORMASI PUBLIK DAN GOOD GOVERNANCE (ANTARA DAS SEIN DAN DAS SOLLEN)
}

\author{
Endang Retnowati \\ Fakultas Hukum Universitas Wijaya Kusuma Surabaya \\ e-mail: endangretnowati49@yahoo.co.id
}

\begin{abstract}
ABSTRAK
Keberadaan Undang-Undang No. 14 Tahun 2008 tentang Keterbukaan Informasi Publik memberikan pencerahan dalam pelaksanaan penyelenggaraan Negara atau pemerintahan. Pelaksanaan keterbukaan informasi publik dalam penyelenggaraan negara atau pemerintahan merupakan perwujudan tata pemerintahan yang baik (Good Governance), dan jaminan kepastian hukum terhadap hak masyarakat untuk mendapatkan informasi yang dibutuhkan serta untuk turut serta dalam mengontrol penyelenggaraan negara atau pemerintahan. Pemerintah harus menyiapkan sarana prasarana, sumber daya manusia yang punya kemampuan (skill) dan kemauan serta komitmen dari seluruh penyelenggara pemerintahan atau badan publik dan aparat atau komponennya, untuk melaksanakannya. Agar apa yang diharapkan dapat diwujudkan dengan baik. Untuk mendukung pelaksanaan undang-undang tersebut diperlukan adanya penegakan hukum yang berkeadilan serta dukungan penegak hukum yang profesional dan yang menjunjung tinggi keadilan.
\end{abstract}

Kata Kunci: keterbukaan informasi publik, tata pemerintahan yang baik.

\begin{abstract}
The Law No 14 Year 2008 about The Openness of Public Information provides enlightenment in the implementation of state or government. Implementation of public information in running the state is the embodiment of good governance. It is the guarantee of law towards human rights to get information needed in participating and controlling the implementation of State or Government. The Government should set up infrastructure, human resources who have skills and willingness as well as commitment of all the administrators or Public Agency and the apparatus to do it and what is expected able to realize it well. To support the implementation of the law, it is required law enforcement fairly and supported by law enforcement professional with the appreciation of justice.
\end{abstract}

Keywords: public information, good governance.

\section{PENDAHULUAN}

Di era globalisasi akses terhadap segala informasi sangat terbuka. Masyarakat dengan mudah mengakses informasi yang dibutuhkan khususnya tentang dunia usaha (swasta). Selama ini kecenderungan dunia usaha yang justru lebih memanfaatkan teknologi informasi dan lebih terbuka terhadap kinerja usahanya kepada publik. Namun seiring waktu dengan berkembangnya pemahaman tentang Negara Hukum Demokrasi dan Negara Kesejahteraan, akses terhadap kinerja dan informasi pemerintahan kini menjadi suatu fenomena global. Pemerintah suatu negara yang ada di dunia kini mulai membuka diri terhadap informasi-informasi tentang penyelenggaraan negara atau pemerintahannya kepada publik.
Negara hukum demokrasi adalah negara dimana pelaksanakan sistem kenegaraannya berdasarkan amanat rakyat, maka sudah sewajarnya dan bahkan merupakan hak rakyat untuk mengetahui informasiinformasi mengenai kinerja atau penyelenggaraan negara dan/atau pemerintahan. Dalam pelaksanaan penyelenggaraan negara dan/atau pemerintahan, pemerintah bertanggungjawab kepada rakyat.

Diutarakan oleh David Banisar dalam bukunya Freedom of Information and Access to Government Record Laws Around the World menyatakan: A new era of government transparency has arrived, it is now widely recognized that the cultute of secrecy that has been the modus operandi of governments for centuries is no longer feasible in global age 
of informations. Government in the informations age must provide informations to succeed (http: //www.depkominfo.go.id).

Indonesia sebagai Negara Hukum Demokrasi, sebagaimana ditegaskan dalam Pasal 1 ayat 2 dan ayat 3 Undang-Undang Dasar Negara Republik Indonesia Tahun 1945 (yang selanjutnya disebut UUD 45), sudah barang tentu pemerintahnya bertanggungjawab dalam hal penyelenggaraan negara atau pemerintahaannya kepada rakyat. Salah satu bentuk tanggungjawab pemerintah disini adalah dengan adanya keterbukaan informasi publik.

Selanjutnya, Pasal 28 F UUD 45 menegaskan bahwa: Setiap orang berhak untuk berkomunikasi dan memperoleh informasi untuk mengembangkan pribadi dan lingkungan sosialnya, serta berhak untuk mencari, memperoleh, memiliki, menyimpan, mengolah, dan menyampaikan informasi dengan menggunakan segala jenis saluran yang tersedia.

Dengan adanya transparansi atas informasi publik tentang kinerja pemerintah dalam melaksanakan penyelenggaraan negara atau pemerintahaannya, membuat masyarakat dapat ikut berpartisipasi aktif mengontrol setiap langkah dan kebijakan yang diambil pemerintah. Sehingga penyelenggaraan pemerintahan dapat dipertanggungjawabkan kepada rakyat.

Pada dasarnya tujuan utama keterbukaan informasi publik di setiap Negara adalah memastikan bahwa lembaga publik akan lebih akuntabel dan kredibel dengan menyediakan informasi dan dokumen sesuai permintaan publik (Bolton, 1996).

Prinsip Keterbukaan Informasi, merupakan salah satu komponen dalam mewujudkan tata pemerintahan yang baik (good governance). Dalam pengaturan Undang-Undang Republik Indonesia No. 32 Tahun 2004 tentang Pemerintahan Daerah (LNRI No. 125 Tahun 2004, TLNRI No. 4437) selanjutnya dalam penulisan ini disebut UU Pemerintahan Daerah, sebenarnya hal tersebut telah diatur di dalam Pasal 20 ayat 1 yakni: Penyelenggaraan pemerintahan berpedoman pada Asas Umum Penyelenggaraan Negara yang terdiri atas: a. asas kepastian hukum; b. asas tertib penyelenggaraan akan suatu Negara; c. asas kepentingan umum; d. asas keterbukaan; e. asas profesionalitas; f. asas akuntabilitas; g. asas efisiensi; h. asas efektivitas; dan i. asas proporsionalitas

Namun demikian dalam Undang-Undang tentang Pemerintahan Daerah tersebut khususnya terkait dengan asas keterbukaan tidak mengatur perihal bagaimana teknis pelaksanaannya, standar layanan keterbukaan, pengawas dan pengawasannya serta sanksi manakala ketentuan yang juga merupakan asas-asas dalam penyelenggaraan suatu pemerintahan tersebut tidak dilaksanakan atau ditaati.

Untuk menjamin kepastian hukum, serta jaminan pelaksanakan hak rakyat untuk mendapatkan informasi publik khususnya terhadap kinerja pemerintah dalam hal penyelenggaraan negara atau pemerintahannya, maka dibentuklah peraturan perundang-undangan yang mengatur tentang Keterbukaan Informasi Publik, yakni Undang-Undang Republik Indonesia No. 14 Tahun 2008 tentang Keterbukaan Informasi Publik (yang selanjutnya disebut UU KIP), (LNRI No. 61 Tahun 2008, TLNRI No. 4846) yang diundangkan pada tanggal 30 April 2008 dan berlaku 2 tahun sejak tanggal diundangkan, berarti tanggal mulai berlakunya adalah 30 April 2010. Perjalanan waktu berlakunya UU KIP kini telah memasuki tahun ke-3.

Berdasarkan uraian tersebut di atas maka yang menjadi permasalahan dalam penulisan ini adalah bagaimanakah pengaturan keterbukaan informasi publik khususnya dalam rangka Good Governance, serta perangkat apakah yang harus dipersiapkan oleh Pemerintah Daerah dalam rangka mewujudkan keterbukaan informasi publik dalam rangka Good Governance.

\section{PEMBAHASAN \\ Pengaturan Keterbukaan Informasi Publik (KIP) dalam rangka Good Governance: Indonesia Sebagai Negara Hukum yang Demokratis (Democratische Rechtsstaat)}

Pernyataan Indonesia sebagai Negara Demokrasi secara tegas dinyatakan dalam Pasal 1 ayat (2) UUD 45: Kedaulatan berada di tangan rakyat dan dilakukan menurut Undang-Undang Dasar. Istilah demokrasi berawal mula dari bahasa Yunani yaitu Demos yang berarti rakyat dan Kratos yang berarti kekuasaan. Yang mana bila digabungkan, artinya adalah kekuasaan rakyat, maka berarti Indonesia adalah negara dengan pemegang kekuasaan tertingginya adalah rakyat. Istilah demokrasi ini telah dikenal sejak abad ke-5 SM, yang pada mulanya merupakan bentuk reaksi terhadap kediktatoran negara, negara Yunani kuno (Masykuri Abdillah, 1999:71).

Black Law Dictionary memberikan pengertian, Democracy: That form of government in which the sovereign power resides in and is excercised by the body of free citizens directly or indirectly through a system of representation, as distinguished from a monarchy, aristocracy, or oligarchy (1990:432).

Menurut Kamus Hukum, Demokrasi (Democracie) berarti bentuk pemerintahan atau kekuasaan yang tertinggi. Dimana kekuasaan tertinggi merupakan 
kekuasaan (kerakyatan). Sedangkan berdasarkan Kamus Dictionary Webster, Demokrasi mempunyai arti pemerintahan oleh rakyat dimana kekuasaan tertinggi berada di tangan rakyat dan dijalankan oleh mereka atau wakil-wakil yang mereka pilih di bawah sistem pemilihan umum yang bebas (Agussalim Andi Gadjong, 2007:35).

Pada dasarnya demokrasi adalah perkembangan dari kebebasan, dimana rakyat bebas menentukan dan menilai kebijaksanaan negara yang menentukan kehidupan rakyat. Demokrasi mempunyai arti penting bagi seluruh masyarakat, sebab demokrasi adalah hak masyarakat untuk menentukan sendiri jalan hidup organisasi suatu Negara (Mahfud M.D., 2000:20).

Demokrasi yang berlaku di Indonesia sebagaimana ditegaskan dalam Pasal 1 ayat 2 UUD 45 tersebut di atas merupakan jenis Demokrasi Konstitusional, sedangkan ciri khas dari Demokrasi Konstitusional adalah gagasan pemerintahan yang demokratis, yakni ada pemerintah yang terbatas kekuasaannya dan tidak dibenarkan bertindak sewenang-wenang terhadap warga negaranya. Pembatasan terhadap kekuasaan pemerintah tersebut diatur dalam konstitusi.

Dalam ketentuan UUD 45, diatur tentang adanya pembatasan kekuasaan terhadap pemerintahan, dan penegasan tentang adanya perlindungan terhadap Hak Asasi Manusia. Disamping itu juga terdapat tiga ide dasar untuk menetapkan suatu sistem pemerintahan yang demokratis, yaitu:Pertama, Ide Partisipasi yang mengandung pengertian bahwa rakyat ikut serta dalam proses pengambilan keputusan dalam bidang politik dan bidang pemerintahan, baik melalui perwakilan maupun secara langsung, dengan pernyataan pendapat baik lisan maupun tulisan yang harus dilindungi secara konstitusi. Kedua, Ide pertanggungjawaban pemerintah terhadap rakyat yang berarti bahwa pemerintah harus mempertanggungjawabkan atas semua tindakannya kepada rakyat (accountability) sebab pemerintah melaksanakan fungsinya berdasarkan wewenang yang diberikan oleh rakyat. Ketiga, Ide Kesamaan, dalam hal ini kesamaan dalam demokrasi, berarti kesamaan berpartisipasi dalam proses pengambilan keputusan dalam hukum dan pemerintahan (Johyn Schwarzmantel, 1994:12 dan 14).

Selanjutnya pada Pasal 1 ayat 3 UUD 45 ditegaskan bahwa: Negara Indonesia adalah negara hukum. Perihal ajaran negara hukum atau negara berdasar atas hukum, Bagir Manan mengemukakan (Astim Riyanto, 2006:27):

Ajaran negara berdasarkan atas hukum (de rechtstaat dan the rule of law) yang mengandung esensi bahwa hukum adalah supreme dan kewajiban bagi setiap penyelenggara negara atau pemerintah untuk tunduk pada hukum (subject to the law). Tidak ada kekuasaan di atas hukum (above to the law). Semuanya ada di bawah hukum (under the rule of law). Dengan kedudukan ini tidak boleh ada kekuasaan yang sewenang-wenang (arbitrary power) atau penyalahgunaan kekuasaan (misuse of power), baik pada kerajaan maupun republik. Secara maknawi, tunduk pada hukum mengandung pengertian pembatasan kekuasaan seperti halnya ajaran pemisahan kekuasaan atau pembagian kekuasaan. Oleh karena itu, ajaran negara berdasarkan atas hukum memuat unsur pemisahan atau pembagian kekuasaan.

Selanjutnya Bagir Manan dan Kuntana Magnar membaginya ke dalam dua arti, yaitu dalam arti umum dan arti khusus. Menurut beliau berdua (Astim Riyanto, 2006:28):

Dalam arti umum, negara berdasarkan hukum (atau negara hukum) adalah negara dimana ada saling percaya antara rakyat dan pemerintah. Rakyat percaya pemerintah tidak akan menyalahgunakan kekuasannya, dan sebaliknya pemerintah percaya bahwa dalam menjalankan wewenangnya, pemerintah akan dipatuhi dan diakui oleh rakyat. Sedangkan dalam arti khusus, negara berdasarkan hukum diartikan bahwa semua tindakan negara atau pemerintah harus didasarkan pada ketentuan hukum atau dapat dipertanggungjawabkan secara hukum.

Apabila suatu negara memenuhi empat syarat atau unsur negara hukum formal yaitu: Pengakuan terhadap Hak Asasi Manusia (yang selanjutnya akan disebut HAM); Pemisahan kekuasaan; Pemerintahan berdasarkan Undang-Undang; dan juga Pengadilan administratif. Maka negara tersebut dapat dikatakan sebagai Negara Hukum Demokratis.

Berpijak pada unsur-unsur negara hukum formal sebagaimana ditegaskan di atas, maka Indonesia dapat dikatakan sebagai negara hukum demokratis. Karena keempat unsur tersebut telah dipenuhi.

\section{Keterbukaan Infomasi Publik di Indonesia.}

Berkaitan dengan pengakuan terhadap HAM, khususnya dalam hubungannya dengan hak atas informasi publik, Pasal 28 F UUD 45 menegaskan:

Setiap orang berhak untuk berkomunikasi dan memperoleh informasi untuk mengembangkan pribadi dan lingkungan sosialnya, serta berhak untuk mencari, memperoleh, memiliki, menyimpan, mengolah dan menyampaikan informasi dengan menggunakan segala jenis saluran yang tersedia.

Dalam negara hukum yang demokrasi, negara dilaksanakan berdasarkan amanat rakyat. Dalam pelaksanaan penyelenggaraan negara, pemerintah bertanggungjawab kepada rakyat. Segala informasi yang dihasilkan dalam hal penyelenggaraan negara merupakan milik rakyat.

Sebagai langkah mewujudkan tata pemerintahan yang baik (good governance) sekaligus mewujudkan bentuk konkrit perlindungan hak asasi manusia maka diperlukan landasan atau instrumen yuridis yang kuat untuk mengatur keterbukaan informasi yang 
transparan, terbuka, partisipatoris dalam seluruh proses pengelolaan sumberdaya publik mulai dari proses pengambilan keputusan, pelaksanaan serta evaluasi (dalam bentuk Undang-Undang, Peraturan Pelaksanaan maupun kebijakan-kebijakan, dan juga Peraturan Daerah), serta instrumen yang lainnya, yakni instrumen materiil (sarana prasarana), dan instrumen kepegawaian (sumberdaya manusia).

Pelaksanaan akan fungsi pemerintahan dilakukan dengan cara mendayagunakan instrumen-instrumen pemerintahan, yang dapat diklasifikasikan menjadi: Instrumen yuridis, meliputi: peraturan perundangundangan (wet en regeling), peraturan kebijaksanaan (beleidsregel), rencana (het plan), dan instrumen hukum keperdataan; Instrumen materiil; Instrumen personil atau kepegawaian; Instrumen keuangan negara.

Penggunaan instrumen pemerintahan dalam rangka pelaksanaan fungsi pemerintahan harus bertumpu pada prinsip-prinsip Negara Hukum dan asas-asas yang mendasari masing-masing instrumen tersebut (W. Riawan Tjandra, 2008:24). UU KIP, merupakan instrumen yuridis dalam rangka pelaksanaan fungsi pemerintah, khususnya dalam rangka menyediakan informasi publik.

Dalam pengaturan pada Pasal 2 UU KIP diatur tentang penyelenggaraan informasi publik yakni: Pada dasarnya informasi publik bersifat terbuka dan dapat diakses oleh setiap pengguna informasi, kecuali untuk informasi yang dirahasiakan sebagaimana diatur oleh undang-undang, kepatutan dan kepentingan umum yang didasarkan pada pengujian tentang konsekuensi yang timbul apabila suatu informasi diberikan kepada masyarakat serta setelah dipertimbangkan dengan pertimbangan untuk melindungi kepentingan yang lebih besar. Setiap informasi publik harus dapat diperoleh oleh setiap pemohon informasi publik dengan cepat, tepat waktu, biaya ringan dan cara sederhana.

Adapun yang dimaksud informasi publik adalah berdasarkan Pasal 1 angka 2 UU KIP, yaitu informasi yang dihasilkan, disimpan, dikelola, dikirim, dan/atau diterima oleh suatu badan publik yang berkaitan dengan penyelenggaraan dan penyelenggaraan negara dan/atau penyelenggara dan penyelenggaraan badan publik lainnya yang sesuai dengan undang-undang ini, serta informasi lain yang juga berkaitan dengan kepentingan publik. Berdasarkan Pasal 1 angka 1 UU KIP: yang dimaksud dengan informasi adalah keterangan, pernyataan, gagasan, dan tanda-tanda yang mengandung nilai, makna, dan pesan, baik data, fakta, maupun penjelasannya yang dapat dilihat, didengar, dan dibaca yang disajikan dalam berbagai kemasan dan format sesuai dengan perkembangan teknologi informasi dan komunikasi secara elektronik ataupun nonelektronik.

Berdasarkan ketentuan Pasal 2 tersebut di atas maka sifat informasi yang wajib disediakan dan diumumkan adalah Maximum Acces Limited Exemption, yakni akses seluas-luasnya terhadap informasi publik dengan pengecualian yang ketat dan terbatas.

Dalam ketentuan pada Pasal 17 UU KIP diatur beberapa pengecualian informasi, informasi yang dikecualikan antara lain: 1. Setiap Badan Publik wajib membuka akses bagi setiap pemohon informasi publik untuk mendapatkan Informasi Publik; 2. Yang dapat mengganggu kepentingan perlindungan hak atas kekayaan intelektual dan perlindungan dari persaingan usaha tidak sehat; 3. Yang dapat membahayakan pertahanan dan keamanan negara; 4. Yang dapat mengungkapkan kekayaan alam Indonesia; 5. Yang dapat merugikan ketahanan ekonomi nasional; 6 . Yang dapat merugikan kepentingan hubungan luar negeri; 7. Yang dapat mengungkapkan isi akta otentik yang bersifat pribadi dan kemauan terakhir ataupun wasiat seseorang; 8. Yang dapat mengungkap rahasia pribadi; 9. Memorandum atau surat-surat antar badan publik atau intra badan publik, yang menurut sifatnya dirahasiakan kecuali atas putusan Komisi Informasi atau pengadilan; 10. Informasi yang tidak boleh diungkapkan berdasarkan undang-undang

Keterbukaan akan informasi publik merupakan suatu kewajiban setiap badan publik yang mana meliputi lembaga eksekutif, yudikatif, legislatif, serta penyelenggara negara lainnya yang mendapatkan dana dari Anggaran Pendapatan dan Belanja Negara (APBN) atau Anggaran Pendapatan dan Belanja Daerah (APBD), dan termasuk juga yaitu organisasi nonpemerintah, baik yang berbadan hukum maupun yang tidak berbadan hukum, seperti lembaga swadaya masyarakat, perkumpulan, serta organisasi lainnya yang mengelola atau menggunakan dana yang mana sebagian atau seluruhnya bersumber dari APBN atau APBD, sumbangan masyarakat, dan/atau luar negeri.

Pada dasarnya, prinsip keterbukaan informasi yang khususnya dalam penyelenggaraan pemerintahan telah diatur dalam Undang-Undang tentang Pemerintahan Daerah. dan juga berpedoman pada asas-asas umum penyelenggaraan negara sebagaimana diatur dalam Pasal 20 Undang-Undang tentang Pemerintahan Daerah; Penyelenggaraan pemerintahan berpedoman pada asas-asas umum penyelenggaraan negara yang terdiri atas: Pertama, Asas Kepastian Hukum, yaitu 
asas dalam suatu negara hukum yang mengutamakan landasan peraturan perundang-undangan yang berlaku, kepatutan, dan keadilan dalam setiap kebijakan. Kedua, Asas Tertib Penyelenggara Negara, yaitu asas yang menjadi landasan keteraturan, keserasian, dan keseimbangan dalam pengendalian penyelenggaraan negara. Ketiga, Asas Kepentingan Umum. Keempat, Asas Keterbukaan, asas yang membuka diri terhadap hak-hak masyarakat untuk memperoleh informasi yang benar, jujur, dan tidak diskriminatif tentang penyelenggaraan negara dengan tetap memperhatikan perlindungan atas hak-hak asas pribadi, golongan, dan rahasia negara. Kelima, Asas Proporsionalitas, asas yang mengutamakan keseimbangan antara hak dan kewajiban penyelenggara negara. Keenam, Asas Profesionalitas, asas yang mengutamakan keahlian yang berlandaskan kode etik dan ketentuan peraturan perundang-undangan yang berlaku. Ketujuh, Asas Akuntabilitas, asas yang menentukan bahwa setiap kegiatan dan hasil akhir dari kegiatan penyelenggara negara harus dapat dipertanggungjawabkan kepada masyarakat atau rakyat, sebagai pemegang kedaulatan tertinggi negara sesuai dengan ketentuan peraturan perundang-undangan yang berlaku. Kedelapan, Asas Efisiensi dan Asas Efektivitas.

Sebagaimana telah dibahas di uraian pendahuluan sebelumnya, bahwa salah satu kelemahan dalam Undang-Undang tentang Pemerintahan Daerah terkait dengan pelaksanaan asas-asas dalam penyelenggaran pemerintahan tersebut tidak mengatur adanya sanksi hukum bila dalam penyelenggaraan pemerintahan itu tidak dilaksanakan berdasarkan asas tersebut. Sehingga dapat dikatakan tidak ada daya paksa bahwa ketentuan tersebut harus dilaksanakan.

Dalam UU KIP, diatur mengenai ketentuan sanksi, sehingga dengan berlakunya UU KIP itu, bila ada badan publik yang tidak melaksanakan ketentuan undang-undang tersebut, dapat dikenakan sanksi yang berlaku sesuai ketentuan UU KIP tersebut. Untuk lebih mengefektifkan penegakan UU KIP ini perlu dibentuk lembaga dan proses penegakannya serta standar layanan informasi publik. Sehingga masyarakat atau pengguna informasi publik dapat melakukan upaya hukum dan mendapat penyelesaian yang baik manakala haknya untuk mendapatkan informasi tidak diberikan sebagaimana mestinya berdasarkan ketentuan undang-undang.

Adanya keterbukaan informasi publik, merupakan bentuk pelaksanaan tata kelola pemerintahan yang baik (Good Governance), dan mencegah adanya segala bentuk Kolusi, Korupsi ataupun Nepotisme. Karena adanya bentuk kontrol dari masyarakat pada kinerja pemerintah (pusat maupun daerah). Dengan adanya keterbukaan informasi publik diharapkan masyarakat menjadi peka, cerdas dan aktif dalam mengontrol proses penyelenggaran suatu pemerintahan. Bahkan salah satu indikator seberapa besar tanggung jawab pemerintah dalam melaksanakan penyelenggaraan pemerintahan dapat diukur dari keterbukaan informasi publik yang telah mereka sediakan.

Dari sisi ekonomi, keterbukaan informasi ini justru memberikan peluang sebagai sarana untuk mempromosikan diri pada masyarakat luas, termasuk negara lain, tentang kinerja, potensi, keunggulan atau keistimewaan yang dimiliki oleh masing-masing (negara atau daerah). Keterbukaan informasi publik dapat menjadi suatu sarana untuk negara atau daerah untuk dapat mengembangkan negara atau daerahnya, sehingga mampu bersaing dalam perdagangan global. Keterbukaan Informasi publik yang mudah diakses setiap saat oleh masyarakat justru membuat lebih efektif dan efisien. Dari sisi ekonomi, justru akan memberikan keuntungan yang sangat besar bagi suatu negara atau daerah.

Oleh karena itu, pemerintah (pusat atau daerah) harus mempersiapkan dan juga membekali dirinya untuk menuju era keterbukaan informasi publik ini. Dalam hal ini meliputi adanya empat instrument sebagaimana yang telah disebutkan di atas, yakni instrumen yuridis, instrument materiil, personil atau kepegawaian (sumberdaya manusia) dan instrumen keuangan atau pembiayaan. Kesiapan bagi personil atau pegawai (sumberdaya manusia) baik dari sisi integritas, moral, budaya ataupun kesadaran untuk melayani, serta kemampuan (skill), merupakan hal yang mendasar. Sebaik apapun sebuah peraturan telah dibentuk namun kalau pelaksananya dalam hal ini sumberdaya manusianya tidak mempunyai kemampuan atau keahlian di bidangnya serta itikad baik, integritas atau budaya melayani yang baik tentu akan percuma. Sarana prasarana (teknologi atau infrastruktur) juga harus dilengkapi, apalagi saat ini era sistem elektronik yang dapat diakses kapan pun dan dimana pun, sehingga masyarakat mendapatkan kemudahan untuk setiap saat memperoleh informasi yang dibutuhkan. Hal yang sangat penting berkaitan dengan pelaksanaan keterbukaan informasi publik, adalah komitmen dari seluruh aspek penyelenggara pemerintahan, karena sebaik apapun sebuah peraturan dibentuk bila tanpa komitmen untuk melaksanakan, maka menjadi sebuah pajangan belaka.

L. Friedman menegaskan bahwa, berkaitan dengan penegakan hukum, ada tiga komponen yang harus dipenuhi yakni: Substansi Hukum, Struktur Hukum 
dan Kultur Hukum, ketiganya komponen tersebut harus terpenuhi (Satjipto Rahardjo, 1986:166).

Jenis-jenis informasi yang menjadi tanggungjawab badan publik yaitu: Pertama, informasi yang wajib disediakan dan diumumkan secara berkala; Kedua, informasi yang wajib diumumkan serta merta; Ketiga, informasi yang wajib tersedia setiap saat; Keempat, informasi yang dikecualikan; Kelima, informasi yang diperoleh berdasarkan permintaan.

Prinsip dasar dalam hal memperoleh informasi publik didasarkan pada prinsip cepat, tepat waktu, dan biaya ringan, dengan alur sebagai berikut: 1 . Pemohon informasi publik mengajukan permintaan untuk memperoleh informasi publik kepada badan publik secara tertulis atau tidak tertulis; 2. Badan publik wajib mencatat nama dan alamat pemohon informasi, subjek, dan format informasi serta cara penyampaian informasi yang diminta oleh pemohon informasi publik; 3. Badan publik yang bersangkutan wajib mencatat permintaan informasi publik yang diajukan secara tidak tertulis; 4. Badan publik terkait wajib memberikan tanda bukti penerimaan permintaan informasi publik; 5. Permintaan disampaikan secara langsung atau dapat juga melalui surat elektronik, nomor pendaftarannya akan diberikan pada saat penerimaan permintaan; 6 . Permintaan disampaikan melalui surat, pengiriman nomor pendaftaran dapat diberikan bersamaan dengan pengiriman informasi; 7 . Paling lambat 10 (sepuluh) hari kerja sejak diterimanya permintaan, badan publik yang bersangkutan wajib menyampaikan pemberitahuan yang tertulis; 8 . Badan publik yang bersangkutan dapat memperpanjang waktu untuk mengirimkan pemberitahuan paling lambat (7) hari kerja berikutnya dengan memberikan alasan secara tertulis; 9. Ketentuan lebih lanjut mengenai tata cara permintaan informasi kepada badan publik diatur oleh Komisi Informasi (Pasal 21 dan 22 UU KIP).

Dalam hal mendukung pelaksanaan UU KIP ini, dibentuk komisi informasi sebagai lembaga mandiri yang berfungsi menjalankan undang-undang ini dan peraturan pelaksanaannya, menetapkan pedoman teknis pelayanan informasi publik dan menyelesaikan sengketa informasi publik melalui mediasi dan/atau ajudikasi nonlitigasi.

Komisi informasi terdiri atas Komisi Informasi Pusat, Komisi Informasi Provinsi, dan juga Komisi Informasi Kabupaten atau Kota (jika dibutuhkan). Anggota Komisi Informasi Pusat berjumlah 7 (tujuh) orang yang mencerminkan unsur pemerintah dan unsur masyarakat. Anggota Komisi Informasi Propinsi dan/ atau Kabupaten atau Kota berjumlah 5 (lima) orang yang mencerminkan unsur pemerintah dan unsur masyarakat Calon anggota Komisi Informasi diajukan oleh Presiden atau Gubernur untuk diuji kepatutan dan kelayakan oleh DPR atau DPRD. Penetapan anggota Komisi Informasi dilakukan oleh Presiden atau Gubernur atau Walikota atau Bupati.

\section{Penyelesaian Sengketa Informasi}

Bila sengketa informasi tidak dapat diselesaikan pada tingkat Komisi Informasi, maka penyelesaian sengketa dilanjutkan dengan tahap pengajuan gugatan melalui Pengadilan Tata Usaha Negara, apabila yang digugat adalah badan publik negara dan pengajuan gugatan melalui Pengadilan Negeri apabila yang digugat adalah badan publik non pemerintah. Pihak yang tidak menerima putusan Pengadilan Tata Usaha Negera atau Pengadilan Negeri, dapat mengajukan kasasi kepada Mahkamah Agung selambat-lambatnya dalam waktu 14 (empat belas) hari sejak diterimanya putusan dari Pengadilan Tata Usaha Negara atau dari Pengadilan Negeri yang bersangkutan.

Bahwa keberadaan komisi informasi disini pada dasarnya adalah untuk mengawal pelaksanaan UU KIP. Namun dalam kenyataannya Komisi Informasi Publik Pusat belum sepenuhnya melaksanakan fungsinya, bahkan dalam beberapa tindakannya itu cenderung menghambat dan juga menghalangi hak masyarakat untuk mendapatkan informasi. Komisi Informasi Pusat telah gagal dalam memenuhi kewajibannya untuk memberikan layanan informasi publik yang baik melalui prosedur permohonan dan juga lalai dalam memenuhi kewajibannya untuk mengumumkan secara berkala informasi publik yang ada dalam penguasaannya. Selain itu adanya hambatan dalam menangani penyelesaian sengketa informasi publik yang disebabkan oleh tidak kompetennya dan tidak cukup kemampuannya (skill) para komisioner Komisi Informasi Pusat dalam menjalankan tugas sebagai mediator dan/atau ajudikator (Muhammad H.S., Liputan Investigasi Publik, 31 Oktober 2011).

Mencermati ketentuan sanksi pidana yang diatur dalam UU KIP tersebut, dapat dikatakan adanya suatu kepastian jaminan perlindungan terhadap hak masyarakat untuk mendapatkan informasi publik. Namun demikian yang kemudian perlu dicermati pula adalah bagaimana penegakannya khususnya apabila ada pihak-pihak atau badan publik yang tidak melaksanakan ketentuan yang menjadi kewajibannya. Sehingga dalam hal ini pentingnya peran penegak hukum: para penyidik, penuntut umum atau jaksa dan hakim yang profesional dan menjunjung tinggi rasa keadilan, mengingat bahwa dalam kasus ini yang berhadapan adalah antara badan publik atau 
pemerintah sebagai pemegang kuasa dengan rakyat yang notabene sebagai pihak yang lemah.

\section{Perangkat yang Dipersiapkan oleh Pemerintah Daerah dalam Pelaksanaan Good Governance}

Pada uraian di atas telah dijelaskan bagaimana pengaturan akan keterbukaan informasi publik. Kini pada gilirannya akan diulas tentang perangkat atau instrumen yang harus dipersiapkan oleh pemerintah daerah, dalam rangka untuk mewujudkan keterbukaan informasi publik dalam rangka Good Governance, selain adanya instrumen yuridis, materiil, personil atau kepegawaian terkait sumber daya manusia (SDM) dan juga instrumen keuangan atau pembiayaan yang mana merupakan instrumen yang harus ada. Kesiapan Personil atau pegawai (SDM) baik dari sisi integritas, moral, budaya atau kesadaran untuk melayani, serta kemampuan (skill), merupakan hal yang mutlak. Sebagus apapun suatu peraturan tanpa didukung adanya SDM serta sarana prasarana yang memadai, maka mustahil bahwa aturan tersebut dapat ditegakkan dengan baik. Dalam banyak hal pengalaman telah menunjukan bahwa kegagalan dalam pelaksanaan maupun penegakan suatu aturan bersumber dari SDM serta sarana dan prasarananya. Maka dari itu, dengan adanya keterbukaan informasi publik ini, dan juga terkait dengan pengelolaan SDM, Notoatmojo menyatakan bahwa, ruang lingkup bagi pengembangan SDM dalam suatu organisasi, mencakup 3 (tiga) pokok kegiatan yang saling berkaitan, yaitu: Perencanaan SDM; Pendidikan dan juga pelatihan sebagai upaya pengembangan SDM; dan Manajemen SDM.

Ketiga pokok-pokok tersebut menurut Tangkilisan, dimaksudkan sebagai berikut: 1. Perencanaan SDM dilakukan untuk mengefektifkan penggunaan SDM, menyetarakan kegiatan SDM dengan tujuan organisasi, dan dapat mengkoordinasikan kegiatan manajemen SDM, serta mengembangkan sistem manajemen SDM; 2. Pendidikan dan juga pelatihan merupakan upaya untuk mengembangkan SDM, terutama dalam rangka pengembagang kemampuan intelektual dan kepribadian manusia; 3. Manajemen SDM adalah cara untuk membuat rencana, mengorganisasikan, mengarahkan, juga mengawasi kegiatan SDM dalam rangka mencapai tujuan organisasi.

Oleh karenanya diperlukan manajemen atau juga pengelolaan SDM yang baik, khususnya dalam hal ini adalah pengeloaan Pegawai Negeri Sipil. Selain itu dukungan sarana dan prasarana yang memadai, apalagi sekarang eranya adalah era teknologi informasi. Selain ketersediaan informasi yang konvensional juga harus didukung oleh ketersediaan informasi yang dapat diakses oleh siapa pun dan dari manapun. Globalisasi dan perkembangan tehnologi mau tidak mau harus diikuti oleh pemerintah daerah dalam melakukan kegiatan pemerintahannya serta pelayanannya. Untuk itu dukungan pembiayaan atau keuangan negara atau pemerintah daerah dalam penyelenggaraan fungsi pemerintahan sangat diperlukan khususnya untuk menyediakan sarana tersebut.

Pembentukan komisi Informasi, sebagaimana diamanatkan oleh UU KIP baik di tingkat daerah propinsi maupun kabupaten atau kota. Mengingat Ketentuan dalam Pasal 24 ayat 1 bahwa pembentukan komisi informasi di tingkat kabupaten atau kota hanya fakultatif (tidak wajib), hanya berdasark kebutuhan, maka dalam perjalanan di tahun ke-3 UU KIP ini, terutama di kabupaten atau kota yang ada di propinsi Jawa Timur, berdasarkan pengamatan penulis belum ada yang membentuk termasuk propinsi sendiri.

Sebagaimana telah ditegaskan dalam Pasal 23 UU KIP, bahwa salah satu fungsi dari Komisi ini adalah menetapkan petunjuk teknis standar layanan informasi publik, inilah yang nantinya akan digunakan sebagai acuan bagi penyedia informasi publik dalam memberikan layanannya serta sebagai pihak yang menyelesaikan sengketa informasi publik melalui mediasi dan/atau ajudikasi nonlitigasi. Sehingga bila lembaga ini belum atau tidak dibentuk, khususnya di tingkat kabupaten atau kota, tentu akan menghambat pelaksanaan dan penegakan UU KIP.

Pada akhirnya adalah komitmen pemerintah daerah melalui kesadaran dari segenap jajaran pelaksana pemerintahan daerah untuk melayani lebih baik dan profesional kepada masyarakat (public servant).

\section{PENUTUP \\ Kesimpulan}

Dari uraian di atas pada akhirnya dapat disimpulkan dalam negara hukum demokrasi seperti Indonesia, keterbukaan informasi publik dalam penyelenggaraan negara atau pemerintahan merupakan hak rakyat. Pelaksanaan keterbukaan informasi publik dalam penyelenggaraan suatu negara atau pemerintahan, merupakan perwujudan adanya tata pemerintahan yang baik (Good Governance). Keberadaan UU KIP memberikan pencerahan dalam penyelenggaraan suatu negara atau pemerintahan dan jaminan kepastian hukum terhadap hak masyarakat untuk mendapatkan informasi yang dibutuhkan dan turut serta mengontrol penyelenggaraan negara atau pemerintahan.

Keterbukaan akan informasi publik berdasarkan pengaturannya bersifat terbuka dan dapat diakses oleh setiap pengguna informasi dengan beberapa 
pengecualian, yang ditetapkan di dalam UU KIP. Perangkat atau instrument yang harus dipersiapkan dalam rangka pelaksanaan keterbukaan informasi publik khususnya oleh pemerintah daerah adalah, SDM (keahlian, mental) dan sarana prasarana yang memadai sesuai perkembangan teknologi informasi.

\section{Rekomendasi}

Untuk mendukung pelaksanaan dari keterbukaan informasi publik dalam rangka Good Governance, maka pemerintah daerah harus menyiapkan sarana prasarana, SDM yang punya kemampuan (skill), dan kemauan serta komitmen dari seluruh penyelenggara pemerintahan atau badan publik (pemerintah pusat atau daerah dan aparat atau komponennya) untuk melaksanakannya.

Pentingnya penegakan hukum yang berkeadilan serta dukungan penegak hukum yang profesional dan yang menjunjung tinggi keadilan.

\section{DAFTAR PUSTAKA}

Buku:

Abdilah, Masykuri, 1999, Demokrasi di Persimpangan Makna, Respons Intelektual Muslim Indonesia 1966-1993, Yogyakarta: Tiara Wacana.

Gadjong, Agussalim A., 2007, Pemerintahan Daerah, Bogor: Ghalia Indonesia.

Mahfud, Mohammad M.D., 2000, Demokrasi dan Konstitusi di Indonesia: Studi tentang Interaksi Politik dan Kehidupan Ketatanegaraan, Jakarta: Rineka Cipta.
Marzuki, Peter Mahmud, 2008, Penelitian Hukum, Jakarta: Kencana Predana Media Group.

Ridwan HR, 2010, Hukum Administrasi Negara, Jakarta: Raja Grafindo Persada.

Riyanto, Astim 2006, Negara Kesatuan, Konsep, Asas dan Aktualisasinya, Bandung: Yapemdo.

Schwarzmantel, J., 1994, The State in Contemporary Society: An Introductions, London: Harvester Wheatssheaf.

Soekanto, Soerjono, 1986, Pengantar Penelitian Hukum, Jakarta: Universitas Indonesia Press.

Soemitro, Ronny, 1994, Metodologi Penelitian Hukum dan Jurimetri, Jakarta: Ghalia Indonesia.

Tjandra, Riawan, 2008, Hukum Administrasi Negara, Yogyakarta: Universitas Atma Jaya Yogyakarta.

\section{Peraturan Perundangan:}

Undang-Undang Dasar Negara Republik Indonesia Tahun 1945

Undang-Undang Republik Indonesia No. 32 Tahun 2004 tentang Pemerintahan Daerah.

Undang-Undang Republik Indonesia No. 14 Tahun 2008 tentang Keterbukaan Informasi Publik.

\section{Jurnal atau Internet:}

Bahan Sosialisasi UU Keterbukaan Informasi Publik - lingkup BSN, http://www.depkomindo.go.id, diunduh 20 Oktober 2011.

Muhammad H.S., Liputan Investigasi Publik, 31 Oktober 2011. 